\title{
Message from the President Joan H. Van Thal
}

\author{
M. B. E., F. C. S. T.
}

The 12th International Congress of Logopedics and Phoniatrics is to take place in Padua, from August 29th till September 4th, 1962. It is sincerely hoped that many readers of "Folia Phoniatrica" will be there. What country could offer a more appropriate meeting place for an organisation so much concerned with the human voice? One can set down a long list of Italians, composers and singers stretching far back into history, as well as those who have made major contributions to scientific knowledge of the vocal organs in health and in illness, but I will refrain from filling too many of the pages of this journal by doing so.

Subjects to be discussed at the congress will not only relate to physiology and pathology of the voice, but cover the whole field of communication. One of the principal reports will be on Functional Dysphonia, another on the Diagnosis of Hearing Defects, the third on Applied Phoniatrics. Numerous other papers, it is expected, will deal with aphasia, stammering (stuttering), articulatory defects and deviate language development; indeed all aspects of speech and language. We look forward to an attendance to rival the record numbers at the 11th Congress in London in 1959.

It is very gratifying that we are to meet in Padua in 1962, after the disappointment some years ago when our place of venue was to have been Italy; it is an ill wind that blows no good, for in the interval the new Centre for Logopedics and Audiology has been opened and with our congress being organised by its

Societates

147

distinguished director, Professor L. Croatto, M. D., with the co-operation of Professor M. Arslan, M. D., we can be sure the 12th Congress will have a cachet of its own.

Summary

The President of the International Association of Logopedics and Phoniatrics hopes to welcome many readers of "Folia Phoniatrica" at the 12th Congress, in Padua, 1962.

Resume

La présidente de $\Gamma$ Association Internationale de Logopédie et Phonoatrie espère accueillir beaucoup de lecteurs de «Folia Phoniatrica» au 12e congrès qui aura lieu à Padoue du 29 août au 4 septembre 1962.

Zusammenfassung

Die Präsidentin der Internationalen Gesellschaft für Logopädie und Phoniatrie hofft, daß sie viele Leser der «Folia Phoniatrica» auf dem 12. Kongreß in Padua, vom 29. August bis 4. September 1962, willkommen heißen kann.

New York Society for Speach and Voice Therapy

Meeting November 18th 1959

Mrs. Regíne Wohlmann gave a report on the Xlth International Congress of Logopedics and Phoniatrics, London, August 1959. 
Lecture: Mrs. Shulamíth Kastein, Differential Diagnosis of Children with Communicative Disorders.

A paper was presented together with a film, both based on a study that was carried out jointly by members of the staff of Columbia Presbyterian Medical Center and Saint Joseph's School for the Deaf, both in New York City. The study is based on the awareness of the ever increasing number of children that are being saved by modern medicine (prematures, birth traumas, anoxias, infants with Kern-icterus, and prenatal damage). In many of these children the first sign of trouble is impairment or lack of language development. Since they appear to be "deaf" or "mute" they are referred to speech and hearing clinics and schools for the deaf. The responsability for assessment and differential diagnostic evaluation rests with a medical team, particularly the otologist and neurologist, and a para-medical team, particularly the speech pathologist and audiologist. Assessment is based on the concept that language development is dependent on many general factors, but especially the action and interaction of the peripheral sense organs and the central nervous system of the growing child. A scheme was presented for the use as a frame of reference, indicating the major channels through which language flows. In order to develop language normally, the child needs sufficiently intact peripheral sense organs of hearing as well as sight and touch to perceive stimuli from the outside world. He further needs sufficient intact central functions to interpret what he hears, sees and feels, and thus to comprehend and use symbole. After symbols have been perceived and interpreted, perceived and aperceived, proper association, 